\title{
PEMERATAAN AKSES PENDIDIKANBAGI ANAK PUTUS SEKOLAH DI PROVINSI NUSA TENGGARA BARAT
}

\author{
I Nyoman Wijana ${ }^{1}$, Muhamad Suhardi ${ }^{2}$ \\ Institut Keguruan dan Ilmu Pendidikan (IKIP) Mataram ${ }^{1,2}$ \\ Ardhysmart7@gmail.com²
}

\begin{abstract}
ABSTRAK
Penelitian ini bertujuan untuk mengungkapkan, menjelaskan, dan medeskripsikan tentang realitas sosial yang terjadi di Nusa Tenggara Barat, yaitu perluasan dan pemerataan akses pendidikan bagi anak-anak terlantar. Penelitian dilakukan dengan menggunakan pendekatan kualitatif, dengan metode fenomenologi. Hasil penelitian ini menunjukkan bahwa akses pendidikan bagi anak-anak terlantar di Nusa Tenggara Barat sangat rendah. Simpulan, Dari aspek ketersediaan saranaprasarana yang difasilitasi Pemerintah Provinsi hanya ada satu-satunya Panti yang menangani pendidikan anak terlantar, berlokasi di kota provinsi yang melayani sepuluh kabupaten/kota. Dari aspek keterjangkauan, anak-anak terlantar sangat sulit menjangkau tempat pendidikan yang disediakan pemerintah, disebabkan oleh faktor kemiskinan, dan jauhnya jarak antar kota di Nusa Tenggara Barat.
\end{abstract}

Kata Kunci: Perluasan, Pemerataan, Akses Pendidikan, Anak Putus Sekolah.

\begin{abstract}
This study aims to reveal, explain, and describe the social reality that occurred in West Nusa Tenggara, namely the expansion and equitable access to education for abandoned children. The research was conducted using a qualitative approach, by phenomenology method. The results of this study indicate that access to education for abandoned children in West Nusa Tenggara is very low. Conclusion, From the aspect of the availability of facilities facilitated by the Provincial Government, there is only one orphanage that handles abandoned children education, located in a provincial city serving ten districts. From the aspect of affordability, abandoned children find it difficult to reach the education provided by the government, caused by poverty, and the distance between cities in West Nusa Tenggara.
\end{abstract}

Keywords: Expansion, Equity, Access to Education, Child Dropouts

\section{PENDAHULUAN}

Salah satu isu kritis yang menjadi masalah pembangunan dalam bidang pendidikan di Indonesia adalah perluasan dan pemerataan akses pendidikan. Perluasan dimaknai sebagai upaya untuk memperluas daya tampung, agar semua warga negara mempunyai kesempatan yang sama dalam memperoleh layanan pendidikan, sedangkanpemerataan dimaknai sebagai upaya untuk mengatasi kesenjangan layanan pendidikan antar wilayah, (Kementerian Pendidikan Nasional, 2010). Dalam manajemen, konsep pemerataan mempunyai dimensi 
pelayanan berkeadilan (equality), sedangkan perluasan merupakan pengembangan jenis tugas-tugas pekerjaan (job enlargement), dengan mengkombinasikan dua jenis pekerjaan atau lebih, sehingga menjadi tugas yang terpisah (Schermerhon, 2010). Perluasan juga dapat diartikan sebagai kreativitas memperbanyak pekerjaan (job creation), sehingga organisasi yang ada dapat ditingkatkan kuantitas yang dihasilkan (Robbins, 2012).

Fakta empiris menunjukkan bahwa, masih terdapat ketimpangan pelayanan pendidikan antara penduduk kota dan desa, antara penduduk kaya dan miskin, serta berbagai ketimpangan lainnya. Provinsi Nusa Tenggara Barat merupakan salah satu provinsi yang tergolong miskin, sehingga banyak terdapat kelompok masyarakat marginal.Salah satunya ialah kelompok anak-anak terlantar. Angka anak-anak terlantar di Nusa Tenggara Barat berdasarkan data Badan Pusat Statistik Provinsi Nusa Tenggara Barat tahun 2011 mencapai 201.699 jiwa yang tersebar di sepuluh kabupaten/kota (Badan Pusat Statistik \& BAPPEDA Provinsi NTB, 2011). Tingginya jumlah anak terlantar tersebut tentu akanmenjadi masalah krusial bagi Pemerintah Provinsi NTB, jika tidak segera dicarikan solusinya.

Memahami kondisi tentang tingginya angka anak-anak terlantar dan akses pendidikan bagi mereka, perlu dilakukan kajian secara mendalam. Salah satu upaya yang mungkin dilakukan untuk memutus regenerasi anak terlantar berupa warisan kelas marginal kepada generasi berikutnya ialah dengan memperluas akses pendidikan bagi mereka. Hal ini sejalan dengan gagasan Tilaar yang mengatakan bahwa pendidikan mempunyai hakikat sebagai pembebasan umat manusia (Tilaar, 2009).

Akses pendidikan bagi anak-anak terlantar, khususnya di Nusa tenggara Barat juga dapat dimaknai sebagai upaya membebaskan mereka agar tidak terisolasi dalam kehidupan sosial hanya dalam komunitasnya saja. Dengan pendidikan diharapkan mereka mampu bebas dalam relasi dan interaksi dengan sesama manusia yang tidak dibatasi oleh sekat-sekat, dan identitas sebagai kelompok marginal, bodoh, dan miskin. Dengan pendidikan diharapkan mereka sanggup mengubah situasi sosialnya. Sejalan dengan gagasan Freire yang menyatakan, kaum tertindas di Brazil haruslah diberikan pemahaman melalui pendidikan, sehingga mereka menyadari bahwa, realitas sosialnya bukanlah sebagai dunia yang tertutup, dan sama sekali tidak ada pintu keluar, tetapi sebagai suatu situasi sementara yang dapat mereka ubah (Freire, 2009).

Beberapa penelitian telah dilakukan dengan didasari atas pentingnya pendidikan bagi kelompok marginal, salah satunya ialah penelitian dengan tema Pemenuhan Hak Pendidikan Anak Penjual Kresek di Pasar Ujung Berung Bandung, yang dilakukan oleh Setiawan dan Wardianti (2010) yang menyimpulkan bahwa komunitas anak-anak penjual kresek di Pasar Ujung berung Bandung tidak terpenuhi hak sosialnya sebagai anak berupa hak memperoleh pendidikan. Fakta yang ditemukan ialah bahwa anak yang bekerja sebagai penjual kresek di Pasar Ujung Berung Bandung menghabiskan waktunya sekitar 6 jam 
per hari, sehingga praktis bagi mereka yang masih sekolah terganggu sekolahnya, dan bahkan sebagian besar mengalami putus sekolah.Untuk mengatasi masalah tersebut maka, dibentuk kelompok belajar dengan maksud agar anak-anak penjual kresek tersebut dapat belajar tanpa ada ikatan waktu dan dapat menyesuaikan dengan pekerjaan mereka (Setiawan, Wardianti, 2010).

Penelitian lainnya yang relevan dilakukan oleh Sumarno (2004) dengan tema model penanganan anak terlantar berbasis kekerabatan di 6 lokasi penelitian yaitu Sumatera Barat, Sulawesi Selatan, Nusa Tenggara Barat, Bali, Kalimantan Barat, dan Daerah Istimewa Yogyakarta. Temuan penelitian ini mengemukakan bahwa sudah terbentuk beberapa kelompok kekerabatan di beberapa daerah penelitian, dengan kegiatan arisan, keagamaan, kegiatan sosial, dan bantuan kepada masyarakat. Namun kegiatan yang terkonsentrasi pada pelayanan anak terlantar belum terprogram. Hasil penelitian ini memperoleh kesimpulan bahwa kosep tentang anak terlantar lebih dipahami oleh masyarakat sebagai anak yang kurang beruntung, yakni anak yang tidak terpenuhi kebutuhan fisik, psikis, dan sosial secara memadai. Sedangkan pemahaman masyarakat tentang kekerabatan cukup baik, serta pemahaman untuk membentuk kekerabatan di tingkat lokal cukup positif. Hal itu merupakan potensi besar dalam menangani masalah anak terlantar. Selanjutnya direkomendasikan bahwa salah satu strategi untuk menangani masalah anak terlantar ialah melalui sistem kekerabatan.

Penelusuran terhadap penelitian selanjutnya yang mengkaji tentang hak-hak sosial anak terlantar juga dilakukan oleh Widodo (2010) yang diberi tema tentang potret remaja terlantar pada Panti Sosial Bina Remaja. Penelitian memperoleh kesimpulan bahwa keterlantaran anak disebabkan oleh rapuhnya ikatan kekerabatan dalam keluarga, lemahnya dukungan sosial kemasyarakatan, minimnya wawasan dan keterampilan kerja, dampak kemiskinan. Empat faktor tersebut menjadi perangkap tumbuh suburnya remaja terlantar, dan jika keempat faktor tersebut masing-masing telah mencapai titik kulminasi yaitu; kemiskinan semakin menguat, kontrol sosial semakin longgar dan terus melemah, keluarga rawan sosial semakin bertambah, dan biaya pendidikan semakin tidak terjangkau, maka jumlah keterlantaran remaja secara kuantitatif akan terus bertambah.

Penelitian lainnya dilakukan oleh Sitepu, Anwar \& Irmayani (2010) yang mengkaji tentang isu-isu penelantaran, pengucilan, dan kerentanan anak di Jakarta Barat. Penelitian ini memperoleh kesimpulan bahwa di wilayan Kota Administratif Jakarta Barat terdapat banyak anak yang mengalami penelantaran, pengucilan, dan kerentanan. Isu penelantaran yang menonjol ialah: balita tidak dibawa ke posyandu, bayi tidak diberi air susu ibu (ASI) eksklusif, anak tidak diimunisasi dasar secara lengkap, anak tidak memperoleh akses atas pendidikan anak usia dini, anak tidak memiliki akte kelahiran, dan anak putus sekolah. Sedangkan isu pengucilan meliputi: anak keluarga miskin dikucilkan dari pendidikan, anak dipekerjakan, anak perempuan dipandang tidak perlu sekolah tinggi. Selanjutnya isu kerentanan meliputi: rawan putus sekolah, rawan terjangkit 
penyakit menular, rawan menjadi korban bencana, rawan menjadi korban pengaruh buruk lingkungan, dan rawan menjadi korban kejahatan. Selanjutnya dijelaskan bahwa yang menjadi akar masalah keterlantaran, pengucilan, dan kerentanan anak di Jakarta Barat adalah kelemahan individual ayah dan ibu, sehingga keluarga tidak mampu melaksanakan fungsinya memenuhi kebutuhan anak (Sitepu, Anwar, \& Irmayani, 2010).

Studi Kebutuhan Pelayanan Anak Jalanan merupakan tema penelitian yang dilakukan oleh Mujiyadi dkk (2011) yang dilakukan di beberapa provinsi yaitu: Lampung, Jawa Barat, Jawa tengah, Jawa Timur, dan Nusa Tenggara Barat. Penelitian ini akhirnya membuat kesimpulan bahwa, anak jalanan merupakan sebagian dari anak terlantar, yang memerlukan pemenuhan kebutuhan dasarnya meliputi; kebutuhan fisik, psikis, sosial, dan spiritual. Bagi anak jalanan, kebutuhan mendesak yang harus dipenuhi ialah kebutuhan pangan, sandang, papan, serta kesehatan. Pada saat yang sama mereka harus diberikan haknya untuk memperoleh pendidikan. Penelitian ini juga menemukan harapan bagi anak jalanan yaitu bahwa, pada dasarnya anak ingin diakui ekksistensinya, dapat mengisi hidupnya dengan wajar, dapat mengikuti pendidikan sampai tingkat tertinggi, dan memungkinkan untuk menyalurkkan bakat dan keterampilan sesuai dengan talentanya (Mujiyadi, 2011). Dari beberapa kesimpulan penelitian tersebut tampak jelas bahwa persoalan anak-anak terlantar dan anak jalanan dapat menjadi indikasi tidak terpenuhinya hak-hak sosial anak, termasuk dalam bidang pendidikan. Oleh karena itu perlu dikaji secara empiris mengenai perluasan dan pemerataan akses pendidikan khususnya bagi anak-anak terlantar.

Secara kuantitatif fakta empiris menunjukkan bahwa, anak-anak terlantar di Nusa Tenggara Barat setiap tahun cenderung meningkat (Badan Pusat Statistik \& Bappeda Provinsi NTB, 2011). Fakta itu sebagai indikasi bahwa perluasan dan pemerataan akses pendidikan belum efektif menyentuh anak-anak terlantar. Penelitian ini bertujuan untuk mengungkapkan, dan mendeskripsikan tentang perluasan dan pemerataan akses pendidikan terhadap anak-anak terlantar di Nusa Tenggara Barat.

\section{METODE PENELITIAN}

Jenis penelitian ini merupakan penelitian kualitatif dengan pendekatan fenomenologi. Pengumpulan data menggunakan teknik wawancara, observasi, dan studi dokumen. Wawancara dilakukan dengan beberapa informan yaitu; anakanak terlantar, petugas pada Dinas Sosial Kependudukan dan Catatan Sipil, petugas pada Dinas Pendidikan Pemuda dan Olahraga, seorang pimpinan pada Panti Sosial Asuhan Anak Harapan Mataram, Pekerja Sosial Masyarakat yang menangani pendidikan anak terlantar, guru-guru di sekolah tempat anak terlantar mendapat pendidikan. Observasi dilakukan dengan cara ikut serta hadir selama 3 bulan dalam kegiatan-kegiatan yang dilakukan di dalam Panti Sosial Asuhan Anak Harapan Mataram, seperti; kegiatan olahraga, kegiatan keterampilan sosial 
dengan membersihkan lingkungan panti, dan juga kegiatan membantu ibu asuh memasak bagi yang perempuan. Kegiatan lainnya berupa pembinaan kerohanian dengan ceramah-ceramah agama yang sifatnya tentatif. Studi dokumen dilakukan dengan mempelajari arsip-arsip yang relevan pada Panti Sosial Asuhan Anak Harapan Mataram, dokumen yang ada pada Badan Pusat Statistik Provinsi, dan dokumen yang ada pada Dinas Sosial Kependudukan dan Catatan Sipil Provinsi NTB.

Penentuan informan sebagai sumber data dilakukan secara purposive, dengan maksud untuk memperoleh data dari informan kunci, informan utama, dan informan tambahan. Sebagai informan kunci ialah seorang pimpinan panti sosial asuhan anak harapan mataram, karena pimpinan panti ini yang paling bertanggungjawab, dan mengetahui banyak hal yang berkaitan dengan pelayanan pendidikan anak terlantar di Nusa Tenggara Barat. Sebagai informan utama ialah Petugas pada Dinas Sosial Kependudukan dan Catatan Sipil yang mempunyai kaitan dengan pendidikan anak terlantar, petugas dari Dinas Pendidikan Pemuda dan Olahraga yang berkaitan, dan anak terlantar yang memperoleh akses pendidikan yang dibiayai pemerintah. Sedangkan informan tambahan ialah guru di sekolah umum sebagai tempat anak-anak terlantar mengikuti pendidikan, orang tua anak terlantar atau keluarganya, dan pekerja sosial masyarakat.

Instrumen pengambilan data selain peneliti sebagai instrumen kunci, juga menggunakan alat perekam, serta kamera untuk mengambil foto-foto. Dalam wawancara dilakukan secara bebas, agar tidak terkesan formal. Dengan demikian data yang diperoleh mengalir sedemikian rupa.Pertanyaan yang diajukan berkisar tentang perluasan dan pemerataan akses pendidikan khususnya untuk anak-anak terlantar di Nusa Tenggara Barat. Jawaban yang diperoleh baik yang direkam maupun yang dicatat kemudian disederhanakan sesuai fokus penelitian, dan kemudian dianalisis dengan rujukan teori-teori yang relevan, serta hasil-hasil penelitian terdahulu yang mempunyai kaitan dengan penanganan permasalahan anak-anak terlantar. Observasi dilakukan dengan pengamatan di Panti Sosial Asuhan Anak Harapan Mataram secara berkala, dengan maksud untuk menjalin keakraban dengan anak-anak terlantar yang ada dalam panti, sehingga mereka dapat diajak berkomunikasi apa adanya, tanpa ada rasa curiga. Laporan penelitian disusun dalam bentuk naratif untuk mencandrakan data dan informasi yang diperoleh secara kualitatif.

\section{HASIL DAN PEMBAHASAN}

Persoalan akses pendidikan bagi anak-anak terlantar di Nusa Tenggara Barat bukanlah masalah yang mudah. Hasil studi dokumen menunjukkan jumlah anakanak terlantar terus meningkat dari tahun ke tahun. Data tahun 2011 mencapai angka 201.699 jiwa. Selain jumlah yang banyak, anak-anak terlantar tersebut tidak terkonsentrasi di ibukota provinsi saja, melainkan tersebar di sepuluh kabupaten/kota dengan jarak jangkau yang jauh. Tabel 1 menunjukkan sebaran 
anak-anak terlantar yang meliputi 10 kabupaten/kota seProvinsi Nusa Tenggara Barat.

Tabel 1

Sebaran Anak-Anak Terlantar Provinsi NTB

\begin{tabular}{clc}
\hline No & \multicolumn{1}{c}{ Kabupaten/Kota } & Jumlah Anak Terlantar \\
\hline 1 & Lombok Barat & 61.100 \\
\hline 2 & Lombok Tengah & 5.384 \\
\hline 3 & Lombok Timur & 84.763 \\
\hline 4 & Sumbawa & 12.438 \\
\hline 5 & Dompu & 2.401 \\
\hline 6 & Bima & 8.869 \\
\hline 7 & Sumbawa Barat & 158 \\
\hline 8 & Kota Mataram & 7.450 \\
\hline 9 & Kota Bima & 2.072 \\
\hline 10 & Lombok Utara & 17.064 \\
\hline & Jumlah & 201.699
\end{tabular}

Sumber :Badan Pusat Statistik \& BAPPEDA Provinsi NTB, Tahun 2011

Dari jumlah anak terlantar tersebut, yang mampu diberikan layanan pendidikan oleh Pemerintah Provinsi Nusa Tenggara Barat sejumlah 80 orang, yang ditampung melalui Panti Sosial Asuhan Anak Harapan Mataram tahun 2011/2012. Panti Sosial Asuhan Anak Harapan Mataram merupakan satu-satunya lembaga milik pemerintah yang menangani pendidikan anak terlantar di NTB. Tabel 2 menunjukkan daftar jumlah anak-anak terlantar yang bernasib lebih baik dibandingkan anak-anak terlantar lainnya yang masih berkeliaran di jalanan.

Tabel 2

Daftar Anak-Anak Terlantar Se.NTB yang Sudah/Belum Mendapat Akses Pendidikan Tahun 2011/2012

\begin{tabular}{llccccc}
\hline \multirow{2}{*}{ No } & Kab/Kota & Jml Anak & Terlayani & \multicolumn{3}{c}{ Belum Terlayani } \\
\cline { 4 - 7 } & & Terlantar & Jumlah & $\%$ & Jumlah & $\%$ \\
\hline 1 & Lombok Barat & 61.100 & 24 & 0.04 & 6.1076 & 99.96 \\
\hline 2 & Lombok Tengah & 5.384 & 12 & 0.22 & 5.372 & 99.78 \\
\hline 3 & Lombok Timur & 84.763 & 11 & 0.01 & 84.752 & 99.99 \\
\hline 4 & Sumbawa & 12.438 & 2 & 0.02 & 12.436 & 99.98 \\
\hline 5 & Dompu & 2.401 & 1 & 0.04 & 2.400 & 99.96 \\
\hline 6 & Bima & 8.869 & 9 & 0.10 & 8.860 & 99.90 \\
\hline 7 & Sumbawa Barat & 158 & 1 & 0.63 & 157 & 99.37 \\
\hline 8 & Kota Mataram & 7.450 & 13 & 0.17 & 7.437 & 99.83 \\
\hline 9 & Kota Bima & 2.072 & - & - & 2.072 & 100.00 \\
\hline 10 & Lombok Utara & 17.064 & 7 & 0.04 & 17.057 & 99.96 \\
\hline & Jumlah & 201.699 & 80 & 0.04 & 201.619 & 99.96 \\
\hline
\end{tabular}

Sumber : Panti Sosial Asuhan Anak Harapan Mataram (diolah)

Data hasil studi dokumen tersebut menunjukkan bahwa anak-anak terlantar yang jumlahnya ribuan orang, baru bisa memperoleh layanan pendidikan sebanyak 80 orang. Hal itu terjadi bukan tanpa alasan. Ditinjau dari aspek sumber daya insani dan sumber daya non insani yang dimiliki Panti sebagai tempat 
layanan pendidikan anak terlantar, faktanya juga sangat minim.Tidak terpenuhinya secara maksimal hak sosial anak terlantar dalam bidang pendidikan, mendapat pengakuan dari petugas Dinas Sosial Kependudukan dan Catatan Sipil Provinsi NTB yang mempunyai tugas berkaitan dengan pendidikan anak terlantar.

Akses pendidikan anak-anak terlantar di Nusa Tenggara Barat, baik dari segi ketersediaan maupun dari segi keterjangkauan mengalami banyak kendala. Terbukti data empiris menunjukkan anak-anak terlantar sebagian besar belum mampu memperoleh akses pendidikan. Salah satu kendala ialah terbatasnya anggaran Pemerintah Provinsi, yang berdampak pada tidak tercapainya perluasan dan pemerataan akses pendidikan.

Perluasan akses pendidikan bagi anak-anak terlantar menjadi penting mendapat perhatian, karena secara faktual jumlah anak-anak terlantar sangat banyak, sedangkan daya tampung panti sosial untuk mefasilitasi anak-anak terlantar mendapat pendidikan sangat terbatas. Dengan keberadaan satu-satunya panti di Nusa Tenggara Barat yang memberikan layanan pendidikan anak terlantar, serta terbatasnya daya tampung, memberi isyarat bahwa perluasan dan pemerataan akses pendidikan hanyalah terbatas wacana normatif saja, dan tidak pernah diimplementasikan.

Bagi anak-anak terlantar yang beruntung difasilitasi panti sosial untuk mendapat pendidikan di sekolah-sekolah umum dari tingkat Sekolah Dasar sampai dengan Sekolah Lanjutan Tingkat Atas, merupakan karunia yang luar biasa. Bahkan bagi mereka tidak pernah terbayangkan akan bisa sekolah seperti sekarang.

Pernyataan tersebut mengandung makna bahwa, meskipun anak-anak terlantar tersebut mempunyai niat yang kuat untuk sekolah, tetapi mereka tidak berdaya untuk memperoleh akses pendidikan. Hal tersebut disebabkan karena keluarganya yang miskin, sehingga tidak mampu untuk membiayai sekolah anakanaknya. Secara umum anak-anak terlantar menghadapi masalah yangg sama, sehingga pendidikan merupakan sesuatu yang sangat mahal bagi mereka.

Selanjutnya pendapat yang senada dikemukakan oleh Kepala Sekolah salah satu SMK Negeri di Mataram. Dalam pandangannya sebagai pendidik, berpendapat bahwa, pendidikan anak-anak terlantar di Nusa Tenggara Barat sesungguhnya bisa dituntaskan, bilamana Pemerintah Provinsi bekerja sama dengan Pemerintah Kabupaten/Kota secara serius untuk memberikan akses sepenuhnya kepada anak-anak terlantar untuk memperoleh pendidikan. Secara fakta dikemukakan bahwa akses pendidikan anak-anak terlantar di Nusa Tenggara Barat sangat terbatas. Lembaga untuk menangani pendidikan anak-anak terlantar yang dibiayai oleh Pemerintah Provinsi hanya ada satu-satunya yaitu Panti Sosial Asuhan Anak Harapan Mataram.Tempat itu tentu saja tidak memadai untuk ratusan ribu anak terlantar dari sepuluh kabupaten/kota. 
Terbatasnya akses pendidikan bagi anak-anak terlantar dinyatakan juga oleh orang tua salah satu anak terlantar yang dibina di Panti Sosial Asuhan Anak Harapan Mataram.Setelah ditinggal mati oleh suaminya, yang bersangkutan membesarkan 6 orang anak dengan pekerjaan menjadi tukang memperbaiki kasur. Beruntung 2 orang anaknya bisa sekolah melalui Panti Sosial. Orang tuanya menceritakan bahwa untuk memperoleh kesempatan bersekolah bagi anakanaknya sangatlah sulit. Karena jangankan untuk biaya bersekolah, bahkan untuk menyediakan makan sehari-hari bagi anak-anaknya sudah cukup kesulitan.Hal ini menjadi gambaran umum bagaimana sulitnya akses pendidikan bagi kelompokkelompok masyarakat marginal, salah satunya anak-anak terlantar.

Pernyataan informan tersebut merupakan cerminan dari keadaan sesungguhnya dari nasib anak-anak terlantar di Nusa Tenggara Barat. Meskipun secara normatif dapat dipahami bahwa pendidikan merupakan hak semua warga negara tanpa terkecuali. Namun pada kenyataannya kelompok anak-anak terlantar masih sangat terbatas untuk memperoleh akses pendidikan.

Berkaitan dengan akses pendidikan anak-anak terlantar di Nusa Tenggara Barat, hasil penelitian menunjukkan bahwa, terjadi ketimpangan yang cukup tajam antara jumlah anak-anak terlantar yang membutuhkan pelayanan pendidikan, dengan ketersediaan sarana-prasarana pendidikan yang disiapkan oleh pemerintah. Hal ini secara faktual menggambarkan bahwa akses pendidikan bagi anak-anak terlantar di Nusa Tenggara Barat berdasarkan perspektif ketersediaan sangat terbatas. Fakta lain menunjukkan bahwa secara kelembagaan, sarana-prasarana pendidikan bagi anak-anak terlantar hanya ada satu-satunya di Ibu Kota Provinsi, yaitu Panti Sosial Asuhan Anak Harapan Mataram.

Sementara itu sebaran anak-anak terlantar berada di sepuluh kabupaten/kota, dengan jarak tempuh yang cukup jauh. Hal ini berarti bahwa, dari perspektif keterjangkauan sarana-prasarana pendidikan bagi anak terlantar juga tidak memadai. Gagasan memperbanyak jenis pekerjaan atau layanan yang mampu mengatasi kesenjangan antar kabupaten/kota menjadi relevan (Schermerhorn, 2010). Senada dengan upaya memperkaya jenis pekerjaan sebagaimana gagasan Robbins (2012) fakta yang dialami anak-anak terlantar di Nusa Tenggara Barat, tidak jauh berbeda dengan anak-anak penjual kresek di Pasar Ujung Berung Bandung, sebagaimana diungkapkan oleh Setiawan, Wardianti (2010) mereka tidak berdaya untuk memperoleh akses pendidikan, disebabkan berbagai faktor, salah satunya faktor kemiskinan keluarga.Gagasan untuk membuat kelompok belajar, meskipun sifatnya sementara, cukup memberi arti bagi upaya perluasan dan pemerataan akses pendidikan bagi kelompok-kelompok masyarakat marginal.

Upaya peluasan dan pemerataan akses pendidikan bagi anak terlantar, secara tidak langsung juga telah direkomendasikan dalam penelitian Sumarno (2004) tentang model penanganan anak terlantar berbasis kekerabatan. Meskipun penelitian ini tidak hanya berfokus pada aspek pendidikan, tetapi pada aspek pelayanan secara umum, seperti; kebutuhan sandang, pangan, papan, kebutuhan 
psikis, dan sosial. Namun pada aspek kebutuhan sosial juga termasuk akses pendidikan. Jika dikaitkan dengan persoalan akses pendidikan anak-anak terlantar di Nusa Tenggara Barat, hasil penelitian Sumarno (2004) yang merekomendasikan untuk membentuk kekerabatan sebagai basis penanganan anak terlantar cukup rasional.

Meskipun mungkin memerlukan proses yang cukup lama dalam implementasinya. Dalam konteks penelitian ini, persoalan perluasan dan pemerataan akses pendidikan anak terlantar, yang dalam faktanya sangat terbatas, sesungguhnya dapat diperluas melalui gerakan nasional pelayanan pendidikan anak terlantar berbasis keluarga. Dengan gerakan nasional pelayanan pendidikan anak terlantar berbasis keluarga, maka alasan Pemerintah Provinsi yang tidak mempunyai anggaran untuk membangun tempat-tempat penampungan anak-anak terlantar tidak relevan lagi, karena pembiayaan dapat dilakukan secara berssamasama antara pemerintah pusat, pemerintah provinsi, dan pemerintah Kabupaten/kota. Pelayanan pendidikan bagi anak-anak terlantar dapat dilakukan dengan memfasilitasi seluruh kebutuhan anak untuk sekolah, dan anak yang bersangkutan bisa tinggal bersama keluarganya, atau bagi yang tidak ada orang tuanya, bisa dititipkan pada keluarga besarnya. Pelayanan pendidikan anak terlantar yang dikelola dalam panti seperti sekarang ini haruslah menjadi pilihan terakhir, jika sama sekali tidak ada alternatif, seperti karena anak-anak tersebut sama sekali tidak ditemukan lagi asal-usul keluarganya.

Pelayanan pendidikan anak-anak terlantar yang dilaksanakan melalui satusatunya lembaga yang disiapkan pemerintah tentu tidak relevan jika ditinjau dari Undang-Undang Dasar 1945 khususnya Pasal 31 Ayat (2) yang menyatakan setiap warga negara wajib mengikuti pendidikan dasar dan pemerintah wajib membiayainya. Pernyataan beberapa informan yang menjelaskan bahwa mereka tidak mampu memperoleh akses pendidikan, yang disebabkan oleh faktor kemiskinan semestinya sudah tidak terjadi, karena sudah seharusnya menjadi kewajiban pemerintah sesuai dengan amanat Undang-Undang Dasar. Namun demikian fakta tersebut masih terjadi di Nusa Tenggara Barat.

Secara teoritis fakta tidak terlayaninya ratusan ribu anak-anak terlantar untuk memperoleh hak sosialnya berupa pendidikan, dapat ditelusuri dari perspektif teori hegemoni Gramsci. Gagasan Gramsci tentang hegemoni bukanlah hubungan dominan dengan menggunakan kekuasaan represif semata-mata, melainkan juga hubungan dominan berdasarkan persetujuan dan konsensus melalui kepemimpinan politik dan ideologis (Mahfud, 2009). Berkaitan dengan tidak berjalannya program perluasan dan pemerataan akses pendidikan di Nusa Tenggara Barat, khususnya bagi anak-anak terlantar merupakan praktek hegemoni pemerintah kepada kelompok masyarakat marginal, dengan menggunakan konsensus dan persetujuan sebagai dasar dominasi dalam pengambilan kebijakan. Seperti pernyataan beberapa informan yang menyatakan hanya sedikit anak terlantar yang terlayani karena anggaran pemerintah terbatas. 
Pada sisi yang berbeda kelompok marginal menyatakan mereka tidak sanggup sekolah karena orang tuanya miskin.

Kebijakan tersebut berjalan secara terus menerus tanpa mendapat penolakan dari pihak manapun, bahkan seolah-olah telah mendapat persetujuan dari masyarakat bahwa hal tersebut wajar terjadi, dengan alasan keterbatasan anggaran pemerintah. Teori hegemoni Gramsci memang sangat berpengaruh dalam perumusan kebijakan pendidikan, khususnya dalam konsep perang posisi dan demokratisasi kehidupan sosial (Tilaar, Nugroho, 2009). Dalam konsep perang posisi pendidikan merupakan sesuatu yang sangat penting dalam upaya peningkatan kemampuan dari kelas masyarakat tertentu. Dalam konteks penelitian ini kelompok masyarakat marginal khususnya anak-anak terlantar mempunyai hak untuk memperoleh layanan pendidikan agar sanggup mengubah kelas sosialnya dalam masyarakat.

Bilamana diberikan akses seluas-luasnya kepada anak-anak terlantar untuk memperoleh pendidikan, maka dapat dimaknai sebagai kesempatan kelompok marginal untuk mengubah posisi kelasnya dalam masyarakat. Gerakan semacam itu telah dilakukan oleh Paulo Preire dalam program pemberantasan buta huruf di Brazil (Preire, 2008). Kajian Widodo (2010) tentang Potret Remaja Terlantar juga merekomendasikan perlunya kebijakan pemerintah dalam menangani masalah remaja terlantar dengan model berkelanjutan. Alasan yang dikemukakan ialah bahwa keterlantaran remaja secara kuantitatif cenderung meningkat, akibat tidak tertanganinya akar keterlantarannya secara memadai. Jika akar keterlantaran mmencapai titik kulminasi seperti; kemiskinan menguat, kontrol sosial melemah, keluarga rawan sosial bertambah, dan biaya pendidikan semakin tidak terjangkau, maka dipastikan remaja terlantar akan bertambah. Dari empat akar keterlantaran remaja yang diungkapkan Widodo dalam risetnya Widodo (2010) salah satunya ialah tidak terjangkaunya biaya pendidikan. Dengan demikian perluasan dan pemerataan pendidikan yang difasilitasi pemerintah akan menjadi salah satu solusi untuk mengurasi pertumbuhan remaja terlantar.

Teori relasi kekuasaan dan pengetahuan Foucault (2002) juga dapat digunakan untuk membahas kebijakan perluasan dan pemerataan pendidikan anak terlantar dari perspektif yang berbeda. Kekuasaan pada hakikatnya bukanlah milik kelas dominan untuk menguasai kelas yang lain, akan tetapi haruslah beroperasi secara produktif dan positif. Kebijakan pemerintah bidang pendidikan anak terlantar bila kita telusuri lebih dalam, maka kebijakan tentang perluasan dan pemerataan akses pendidikan anak terlantar di Nusa Tenggara Barat belumlah produktif dan positif.Argumentasi logisnya ialah bahwa kekuasaan yang ada pada pihak pengambil kebijakan yaitu pemerintah, tidak mampu secara produktif mengoptimalkan perluasan dan pemerataan akses pendidikan, sehingga banyak anak-anak terlantar yang tidak terlayani hak sosial mereka berupa pendidikan. Fakta empirisnya ialah bahwa kebijakan pelayanan anak terlantar hanya melalui Panti Sosial Asuhan Anak Harapan Mataram, dan merupakan lembaga satu- 
satunya di kota provinsi. Sedangkan anak-anak terlantar tersebar dalam jumlah yang relatif besar di sepuluh kabupaten/kota. Perspektif relasi kekuasaan dan pengetahuan memberi ruang untuk membongkar segala bentuk dominasi, sehingga terbentuk relasi yang setara. Hanya dengan demikiankekuasaan dan pengetahuan tidak menjadi milik tetapi justru menjadi strategi.

Penelitian ini perspektif relasi kekuasaan dan pengetahuan dapat dimaknai bahwa kekuasaan dan pengetahuan yang ada pada berbagai pihak, khususnya pemerintah haruslah digunakan sebagai strategi untuk mengentaskan anak-anak terlantar dari kebodohan, keterbelakangan, dan keterasingan dari lingkungan sosial, dengan memberi akses pendidikan dengan melakukan perluasan dan pemerataan akses pendidikan bagi mereka.

Keterbatasan akses pendidikan bagi anak-anak terlantar, meniscayakan terjadinya generasi yang hilang di masa mendatang. Selain itu juga berdampak pada terjadinya reproduksi kelas marginal secara terus menerus. Karena sebuah kelas tertentu dalam masyarakat dapat dipastikan akan mewariskan hak istimewanya kepada generasi berikutnya. Kelas masyarakat marginal akan mereproduksi kelas marginal, dengan demikian mata rantai reproduksi kelas anak terlantar tidak pernah terputus. Akses pendidikan menjadi sangat penting untuk memampukann anak-anak terlantar memutus mata rantai reproduksi kelas yang sama, sehingga mereka mampu meningkatkan kelasnya terhadap dirinya sendiri dan generasi berikutnya. Fakta yang senada diungkapkan dalam penelitian Anwar Sitepu dan Irmayani di Jakarta Barat. Penelitian dengan tema Isu-Isu Penelantaran, Pengucilan, dan Kerentanan Anak, salah satu kesimpulannya ialah bahwa penelantaran anak di Jakarta Barat disebabkan oleh orang tuanya yang tidak berdaya baik secara ekonomi, maupun secara sosial. Hal itu berarti telah terjadi reproduksi kelas yang tidak berdaya secara turun temurun.

Gagasan tersebut selain sejalan dengan teori reproduksi kelas Bourdieu (2009) juga sangat relevan dengan teori praktik sosialnya yang didasari konsep habitus, modal, dan ranah. Habitus anak-anak terlantar yang tidak memperoleh akses pendidikan dalam waktu lama dan terus menerus terinternalisasi dalam diri mereka, dan membentuk praktik-praktik kehidupan sosial. Habitus yang terinternalisasi ke dalam setiap anak terlantar, akan termanifestasikan dalam interaksi dengan lingkungan sosialnya menggunakan berbagai macam bentuk. Seperti tingkah laku, cara berbicara, cara berpakaian, bahkan juga ide-ide mereka. Dalam tingkat ide misalnya, mereka cenderung berpikir hal-hal pragmatis seperti; berpikir tentang bagaimana caranya hari ini bisa makan dan bertahan hidup. Seperti hasil wawancara dengan beberapa informan menyatakan bahwa mereka tidak terbayangkan untuk bisa memperoleh pendidikan, karena kondisinya ekonoomi mereka.

Hal itu menunjukkan ranah perjuangan mereka sangat terbatas, disebabkan habitus yang terinternalisasi pada kelas marginal, dan juga tiadanya modal ekonomi, modal sosial maupun modal budaya. Untuk mengubah situasi sosial 
yang demikian maka diperlukan sentuhan program pemerintah berupa perluasan dan pemerataan akses pendidikan, sehingga semua anak-anak terlantar dapat menikmati sarana dan prasarana pendidikan baik dari segi ketersediaan maupun dari segi keterjangkauan.

\section{SIMPULAN}

Provinsi Nusa Tenggara Barat, Perluasan dan Pemerataan akses pendidikan khususnya bagi anak-anak terlantar, masih sangat minim. Ditinjau dari aspek ketersediaan sarana-prasarana pendidikan, hanya ada satu-satunya lembaga pemerintah yang menangani pendidikan anak terlantar, sedangkan jumlah anak terlantar cukup banyak dan tersebar di 10 kabupaten/kota. Dari aspek keterjangkauan juga sangat rendah, karena daya tampung panti hanya 80 orang per tahun, disebabkan oleh karena anggaran pemerintah terbatas, sehingga tidak sanggup menjangkau seluruh anak-anak terlantar yang membutuhkan layanan pendidikan.

Program perluasan dan pemerataan akses pendidikan untuk seluruh warga negara masih bersifat normatif, belum dapat diimplementasikan secara nyata. Diperlukan adanya kemauan politik pemerintah untuk mengimplementasikan program tersebut secara nyata, agar semua warga negara dapat memperoleh akses pendidikan. Khusus pelayanan pendidikan anak terlantar, perlu ada gerakan nasiona pendidikan anak terlantar berbasis keluarga, yang dibiayai pemerintah secara bersama-sama antara pemerintah pusat, pemerintah provinsi, dan pemerintah Kabupaten/Kota.

\section{DAFTAR PUSTAKA}

Badan Pusat Statistik Provinsi Nusa Tenggara Barat Kerjasama dengan Bappeda Provinsi NTB. (2011). Nusa Tenggara Barat dalam Angka, Mataram: BPS Provinsi NTB

Bourdieu, P. (2009). Habitus, Modal dan Ranah, Pengantar Paling Komprehensif Kepada Pemikiran Pierre Bourdieu. Bandung: Jalasutra

Foucault, M. (2002). Wacana Kuasa Pengetahuan. Yogyakarta: Bentang Budaya Freire, P. (2008). Pendidikan Kaum Tertindas. Jakarta: Pustaka LP3ES Indonesia Kementerian Pendidikan dan Kebudayaan. (2010). Rencana Strategis Departemen Pendidikan Nasional Tahun 2010-2014

Mahfud, C. (2009). 39 Tokoh Sosiologi Politik Dunia.Surabaya: Jaring Pena Lini Penerbitan JP Books

Mujiyadi, B. (2011). Studi Kebutuhan Pelayanan Anak Jalanan. Jakarta: P3KS Press

Robbins, S. P., \& Coulter, M. (2012). Management England: Pearson Education Limited

Setiawan, H. H., \& Wardianti, A. (2010). Kelompok Belajar Kancil Sebagai Upaya Pemenuhan Hak Pendidikan Anak Penjual Kresek di Pasar Ujung Berung, Jakarta: Jurnal Penelitian dan Pengembangan Kesejahteraan Sosial, 15(2) 
Schermerhorn, J. R. (2010). Introduction to Management, USA: John Wiley \& Son Inc

Sitepu, A., \& Irmayani, I. (2010). Isu-Isu Penelantaran, Pengucilan, dan Kerentanan Anak di Jakarta Barat, Jakarta: Jurnal Penelitian dan Pengembangan Kesejahteraan Sosial, 15(3)

Sumarno, S. (2004). Model Penanganan Anak Terlantar Berbasis Kekerabatan. Jakarta: Puslitbang UKS-Balatbang Sosial-Departemen Sosial RI

Tilaar, H. A. R. (2009). Kekuasaan dan Pendidikan, Manajemen Pendidikan Nasional dalam Pusaran Kekuasaan. Jakarta: PT. Rineka Cipta , \& Nugroho, R. (2009). Kebijakan Pendidikan. Yogyakarta: Pustaka Pelajar

Widodo, N. (2010). Potret Remaja Terlantar Studi Kasus pada Panti Sosial Bina Remaja (PSBR). Jurnal Penelitian dan Pengembangan Kesejahteraan Sosial, 15(1) 